\title{
Economics
}

\section{Cyclical Balanced Development of Economy and Society for Full Employment and National Happiness}

\author{
Bark Soon IL \\ Korea Social Policy Institute, Seoul, Republic of Korea \\ Email address: \\ barksoonil-ui@hamail.net

\section{To cite this article:} \\ Bark Soon IL. Cyclical Balanced Development of Economy and Society for Full Employment and National Happiness. Economics. \\ Vol. 8, No. 1, 2019, pp. 20-34. doi: 10.11648/j.eco.20190801.14
}

Received: November 22, 2018; Accepted: March 4, 2019; Published: March 20, 2019

\begin{abstract}
The ultimate goals of the economy are full employment and promoting the happiness of the people. This paper analyzes empirically the failures to achieve full employment and national happiness promotion despite long-term economic development in the economic policies of liberal, socialist, and socio-democratic regimes. It is emphasizing unused resources such as chronic unemployment and surplus of capital as the main reasons for these failures. To fulfill these main purposes, a cyclical equilibrium development model of economy and society is suggested here. The roles of civilians are also stressed to complement the failures of the market and governments. And To achieve the flexible movement of labor and the complete use of surplus labor and excessively accumulated capital, the monopolization of the markets, governments, and civil bodies including large unions of labor and professional occupations must be removed. The employment of workers with relatively weak labor abilities is contributory to enhancing national happiness by increasing social as well as economic value especially in the period of economic depression. Policy directions and several measures including deregulation of markets, the punitive taxations on the preventions of labor mobility and excessive replacement of labor with capital intensive methods, and the expansion of social enterprises are also provided to enable the model to be applied in Korea.
\end{abstract}

Keywords: Full Employment, National Happiness Index, Cyclical Equilibrium Development, Market Liberty, Economic \& Social Value, Citizen's Public Service Participation

\section{Introduction}

The ultimate purpose of economic and social policy is enhancing national happiness, through full employment. Because work is one of the most important elements of individual happiness, it is not too much to highlight full employment because of important influence of labor on life. Economic development over last several centuries has achieved enhancement of national happiness, expansion of employment and higher quality of labor. Nonetheless, full employment has not been accomplished and the enhancement of national happiness has also been unsuccessful in any economic policies and social security systems of liberalism, socialism and social democracy until now. The efficiency of free market economy has led the world after socialist states collapsed early in 1990s. The chronic unemployment rate has still remained high not only because of business fluctuation but also because of structural problems such as advancements of labor saving technology and increases of the disadvantaged workers owing to aging. Although social security policies that intervene more in the market to increase employment and stabilize livelihood have been expanded for a long period, gross national happiness is not satisfactory and poverty and distribution problems are still very huge.

Economics as a social science should be an empirical study that basically deals with human livelihood. If, without reflecting human's lives and diverse desires, it places them in ideological structure like pure economic order as in an extreme liberalism, many problems would occur far from real human desires. In socialism, especially, an autocratic socialist economy, full employment is only achieved by government allocation of labor to assigned work places but with almost negligible pay. The mixed systems overcoming extreme liberalism and nationalism are not successful in accomplishment of national happiness enhancement and full employment. Social policies to correct capitalistic market failures or to increase social benefits, have failed to accomplish them because politicians and bureaucrats have 
inclined to politicize public programs to maintain and strengthen their power. Therefore, full employment and enhancement of national happiness cannot be accomplished only by economic development or increased government social investment.

In this paper, despite increased income through economic development, the failures to accomplish full employment and enhance national happiness are empirically analyzed. Based on the evidences, this paper suggests the balanced circular economic and social development model, a comprehensive model to attain the important objects of full employment and the enhancement national happiness.

In this model, labor is one of the most important elements of national happiness because it determines quality of life, and labor itself improves poverty, distribution and social problems. Thus, labor produces not only economic value but also social value. Especially disadvantaged laborers' participation in social value production can be an important way to accomplish full employment. In the circular model, society is not developed lagging after economic development. Through promoting full employment of the surplus labor socially, full employment could be continuously maintained, and economy and society can enhance national happiness cyclically by their participation in producing social value during economic depressions and producing economic value during economic booms.

For this purposes, government business should prefer the way of increasing employment to economic efficiency. To overcome the red-tape curse of governments and political systems, citizens who are well aware of various needs of the disadvantaged could absorb them into full employment by founding and vitalizing social enterprises or cooperatives. In this model, individual free economic activities are also emphasized to maximize social and economic value. To realize this model, human's economic desires should not be constrained by political ideology and unrealistic economic logic, and practical and comprehensive academic effort and policy decision are needed.

\section{Failure in Accomplishment of Full Employment and Increase of National Happiness}

Most advanced European countries have increased their social welfare budgets without sufficiently satisfying basic standards of living and reducing unemployment, poverty, social, and environmental problems. First, despite continuous economic development and increase in income after the appearance of revised capitalism in the 1930's, high levels of chronic unemployment as well as cyclical unemployment owing to business fluctuation are holding out. As Table 1 shows, the unemployment rates in Sweden and Denmark have increased or lasted high levels since the 1990's, and France is holding at nearly $10 \%$. The UK succeeded in reducing the rate, but the level reaches average $4.3 \%$ from 2010 to 2014. On the other hand, due to expanded government interference in the economies of the Organization of Economic Corporation and Development (OECD) countries, the growth rate of social expenditure including labor market expenditure outstrips the growth rate of national income from $15.6 \%$ in 1980 to $22.1 \%$ in 2011 .

Table 1. Average results of economic and social policies in major countries.

\begin{tabular}{|c|c|c|c|c|c|c|c|c|c|}
\hline & & Korea & Japan & USA & UK & Germany & France & Sweden & Denmark \\
\hline \multirow{3}{*}{$\begin{array}{l}\text { economic growth } \\
\text { rate }\end{array}$} & $1990 \mathrm{~s}$ & 7.6 & 1.7 & 3.2 & 1.9 & 2.2 & 2.0 & 1.1 & 2.5 \\
\hline & $2000 \mathrm{~s}$ & 3.8 & 0.6 & 1.8 & 2.0 & 0.8 & 1.4 & $2 . .0$ & 0.9 \\
\hline & 2001-09 & 3.7 & 0.2 & 2.2 & 1.7 & 2.0 & 1.0 & 2.4 & 0.5 \\
\hline \multirow{3}{*}{ (\$)per capita income } & $1990 \mathrm{~s}$ & 9,657 & 34,534 & 28,374 & 21,356 & 26,884 & 24,978 & 29,182 & 30,691 \\
\hline & 2000-09 & 16,696 & 36,318 & 43,111 & 36,890 & 34,443 & 34,929 & 41,785 & 46,427 \\
\hline & 2010-14 & 25,105 & 43,688 & 52,425 & 45,130 & 46,554 & 44,389 & 59,341 & 60,823 \\
\hline \multirow{2}{*}{$\begin{array}{l}\text { rate of social } \\
\text { expenditure }\end{array}$} & $1990 \mathrm{~s}$ & 3.6 & 13.4 & 14.5 & 18.6 & 25.1 & 27.9 & 31.6 & 27.1 \\
\hline & $2010-11$ & 9.3 & 22.6 & 19.2 & 22.8 & 26.2 & 31.6 & 27.6 & 30.0 \\
\hline \multirow{3}{*}{ unemployment rate } & $1990 \mathrm{~s}$ & 3.3 & 3.1 & 5.8 & 8.2 & 7.9 & 11.4 & 7.1 & 7.4 \\
\hline & 2000-09 & 4.0 & 4.6 & 5.5 & 5.3 & 7.9 & 8.8 & 6.5 & 4.5 \\
\hline & 2010-04 & 3.4 & 4.3 & 8.1 & 4.3 & 5.7 & 9.6 & 8.1 & 7.2 \\
\hline \multirow{2}{*}{ Gini coefficient } & rate of change & - & 0.4 & 0.5 & 0.8 & 0.7 & -0.1 & 1.1 & 0.5 \\
\hline & size & 0.32 & 0.33 & 0.38 & 0.34 & 0.30 & 0.29 & 0.26 & 0.25 \\
\hline \multirow{2}{*}{ poverty rate } & rate of change & - & 1.3 & -0.1 & 2.2 & 2.1 & -0.2 & 3.7 & 0.1 \\
\hline & size & 15.0 & 15.7 & 17.3 & 11.3 & 8.9 & 7.2 & 8.4 & 6.1 \\
\hline
\end{tabular}

Note 1: The change of Gini coefficient and the poverty rate is annual average change rate from the mid 1980s to the late 2000s. The poverty rate is population ratio below $50 \%$ of the equalized median income.

Note 2: Social expenditure, which is public social welfare expenditure, includes old age, the bereaved, incapacity to work, health care, positive labor market policy, unemployment, dwelling and the others. Social expenditure in Korea is average of 2010, 2011, and 2013.

Sources: The tables in [25] page 67 and page 69's and [1] page 212-218 are used /.

Second, there has been no or minimal improvement in distribution even though governments' social expenditure has increased chiefly with social welfare. All countries in Table 1 show little rises of average rate of change of Gini coefficient after the mid 1980's, with the exception of France. The average rate of change in $28 \mathrm{OECD}$ countries in the same period is $0.3 \%$, which is very small and their average Gini coefficient of the late 2000 's is 0.31 [25]. In Sweden, which is a representative social 
democratic country, the Gini coefficient rose after the mid 1980's and showed second highest, average increasing rate $1.1 \%$ after the highest Finland $(1.2 \%)$, Denmark $(0.5 \%)$ and Germany $(0.7 \%)$ follow and share the similar system.

Third, average change rate of poverty incidence is negative only in 7 countries, over about 25 years including Belgium, Greece, Portugal, Spain and Chile. Throughout the OECD, the average increasing rate is $1.0 \%$ in the same period, and the level of poverty rate in the late 2000 's is as high as $11.1 \%$.

While governments have replaced some role of market to correct failures of free market, the governments' failure have been just as substantial. Hence, each country is looking for a new economic and social model, called 'the third way'. Neither Europe with big social expenditure rate compared to per GDP nor other liberal countries as the UK, USA and Japan with relatively small rates, are successful in improvement of unemployment, poverty, and distribution problems.

\subsection{Failure of Full Employment}

To overcome unemployment problems, many theories and ideologies such as Marx's communism, Keynes' aggregate demand management theory, neo liberalism and others have been developed. However, despite continuous economic development for more than 200 years, full employment has never been accomplished. Whatever the names, like natural rate of unemployment, frictional unemployment, or cyclical one as a result of business cycle, substantial levels of unemployment have always existed and it may become a main cause of human unhappiness. Marx supposes that the accumulation of capital and the occurrence of massive unemployment is the fate of capitalist system, and neo liberalists supposes the natural rate of unemployment is unavoidable to stabilize inflation, ${ }^{1}$ and Schumpeter thought that there is no way to avoid unemployment in the process of replacing traditional industry with innovative technological advancement. However, it is historically being identified that despite any logical and political alternatives, certain levels of continuous or temporary mass unemployment are inevitable.

The relationship between economic growth and unemployment is uncertain and governments' unemployment policies also face difficulties. The increase and existence of unemployment is due to not being developed enough to absorb new enterer and existing unemployed people in labor market, or it is because economic development occurred just by increasing capital and labor saving technology. Therefore, the effect of labor employment has decreased in comparison with growth of capital and economy. And demand for domestic labor has been also decreased by foreign labor's participation in domestic markets and increased investment in foreign markets. All these factors should be analyzed in more detail. However, in this paper, whether economic growth influences decrease of unemployment rate will be

1 According to Friedman and Phelps' hypothesis, there is the natural rate of unemployment that the government policy doesn't influence unemployment rate, but just fluctuates price. only analyzed to find the relationship empirically.

\subsubsection{Analysis of Chronic Continuation of Unemployment}

The relationships between economic growth rates and unemployment rates are compared especially and also with their change rates of main 16 OECD countries which are more economically developed including Korea. It is supposed that Korea and Germany have a significant correlation but the others could not display significant correlations. Even with the econometrics analysis, a similar result is produced and we get the meaning below. [14]

Firstly, estimating the relation between levels of growth rate and unemployment rate by country, the growth rate statistically gives meaningful influence to the unemployment rate only in Korea, Israel and Germany. ${ }^{2}$ But even in Korea and Israel, $1 \%$ increase in growth rate decreases the unemployment rates just by respectively $0.076 \%$ and $0.065 \%$. Furthermore, in Germany, the estimated coefficient value is negative which doesn't have logical meaning. Looking at each country's relation between the changes of two variables from the previous year, no significant estimation appears excluding Korea and Australia. ${ }^{3}$ And in pooling data analysis by adding countries' dummy variable, the growth rate couldn't give meaningful influence to the unemployment rate. But when estimating the relation between the changes of two variables, the average change of growth rates is estimated to give important influence to change of the unemployment rate. However, the average change rate of unemployment rates in the world is also estimated at only $0.065 \%$ with respect to the $1 \%$ change of world growth rate. This means that after 1990's in advanced countries, the economic growth rate generally influences very slightly or negligibly the unemployment rate.

Secondly, on the contrary, the constant term shows a very large and significantly estimated value in the regression analysis. In the formula estimated by pooling 16 countries' data, the estimated value of constant term is 3.99 though the actual average unemployment rate is 6.59 (standard deviation is 2.51). Therefore, a huge part of unemployment rate estimation is occupied by the constant term.

Thirdly, in representative liberalist countries like USA and the UK, the estimation result of the national income growth variable isn't that meaningful, but the constant term estimation is significant and very high. And similarly in relatively socialistic economic system such as Sweden and Denmark, the result is nearly identical. Therefore the relation between the two variables is irrelevant to ideology difference of the countries ${ }^{4}$.

\footnotetext{
2 Korea $\mathrm{u}=4.598-0.18 \mathrm{Yg}$

(8.17) $(-2.36)$

Israel $\mathrm{u}=9.763-0.131 \mathrm{Yg}$

(20.39) (-2.00)

$\mathrm{U}$ : Unemployment rate, Yg : Economic growth, ( )is value of ' $\mathrm{t}$ '

3 Estimation of Korea's growth rate change variation variable's parameter is 0.064 and the't' value is -4.11 , and Australia's value are -0.276 and -2.55 .

4 Estimated values of constant term and growth rate variation of USA are $6.118(\mathrm{t}$ value 10.723) and -0.231(t value -1.306) respectively, for England are 8.091(t value 8.480$)$ and $-0.530(\mathrm{t}$ value -1.569$)$ each, for Denmark $6.476(\mathrm{t}$ value 6.920$)$ and $-0.153(\mathrm{t}$ value -0.427 ), and Sweden 5.691(t value 7.218) and 0.391(t value
} 
As the result, first, the unemployment rate statistically has no relation with the growth rate of national income or has a very small relation, and this occurs irrespectively of market operation systems or sizes of government's role. Second, 3$10 \%$ of unemployment rate remains in any state of boom or recession, and so a new paradigm is needed to solve the unemployment problem. ${ }^{5}$

\subsubsection{Analysis of Chronic Duration of Unemployment}

Looking at the tendency of unemployment incidence (in terms of one week) in Korea from 1963 to 2015, the longterm unemployment rate has decreased. But after 1990's, the unemployment rate does not show decreasing tendency despite continuous economy growth, the long-term unemployment rate especially after 1998 financial crisis is very stagnant. On the contrary, the national income growth rate is steady decreasing.

Seeing the relation between the unemployment rate and the economic growth rate in Korea, there are differences depending on whether the economy belongs to prosperous or depressed periods and to the level of economic growth rate or growth stages.

First, the influence of economic growth rate on unemployment seems to be clearer in recession. Unemployment naturally increases because investment decreases in recession and therefore, new demand for labor diminishes and layoffs in marginal businesses increase. When the economy growth rate was around $0 \%$ in the depression such as during oil shocks, financial crisis and the global financial crisis periods in Korea, the unemployment rates were multiplied compared to other years. This means that a serious recession in economy augments the unemployment rate in short term.

Second, when the economy is prosperous, the decreasing impact on unemployment is not as clear. The expectation that a high economic growth rate would reduce the unemployment rate could be met only during the late 1960s to the early 1970s. After those periods, the unemployment rate has not reacted to the economic growth rate excluding the year 1986, 1987, 1988 and 1999 when unemployment rates dropped largely by $0.6 \sim 0.7 \%$ owing to the high growth rate of approximately $10 \%$,

When examining the whole period of economic growth including boom and recession, a negative effect appears between the economic growth rate change and unemployment rate change until the early 2000s, but the unemployment rate has not seemed to react, remaining in $3 \%$ range, sensitively to the growth rate change since then. As a result, the correlation between two is just 0.049 and even is not significant in the analysis period after 1963.

1.586).

516 countries' average unemployment rate and growth rate is $6.60 \%$ and $2.27 \%$ each. See in this high and long term unemployment rate, Neo liberalists supposition about natural unemployment rate is too ivory-towered to be justified. This could be interpreted as extreme liberalists' alternative concept in response to the realization that classical school's hypothesis saying full employment can be accomplished in liberalistic market isn't realistic.
Third, while a highly statistically significant relation appears when doing regression of both variables' amount of change from the previous year, ${ }^{6}$ the unemployment rate decreases only by $0.088 \%$ when the growth rate increases $1 \%$. It implies the past active labor policies targeting unemployment of the disadvantaged and younger generation, was not effective. The different reaction of unemployment rate to economic growth according to the growth stages explains such a week response. Estimating by dividing the state into two parts, the growth rate gives meaningful influence to the unemployment rate in state 1 , and no meaningful result appears as expected in state 2 . State 1 is supposed to be in the rapid economic growth period. Therefore in Korea like in other OECD countries, the economic growth rate seems not to give meaningful influence to unemployment rate, and even though influence appears, it seems not to be at expected level.

As results, first, despite many economic policies for job creation, they are not effective or meager in decreasing unemployment in the long-term economic growth. Second, unemployment rate might decrease flexibly in the rapid economy growth stage when labor employment expands extensively along with economic growth. And in medium growth stage of maturing economy when the effect of extensive labor absorption in industry becomes little, the unemployment rate might not be reduced flexibly because it doesn't decrease as fast as the economic growth. And in low economic growth rate stage when economic growth depends on technical innovation, especially labor saving techniques and production systems, the relation between two is supposed to be very inelastic or insignificant. Third, a certain level of unemployment rate should be acknowledged to exist continuously regardless of the economic growth rate. Even though growth rate rises largely, 3 or $4 \%$ of unemployment rate can last in this economic structure and system of Korea. Therefore, there is some limit in reducing unemployment rate only by the automatic conciliatory market function and planned government policies.

\subsubsection{Causes of Duration of Unemployment Rate}

i. Failure of full usage of capital: enlargement of inactive capital accumulation

When new innovation doesn't appear fast enough on time, companies would prepare for future investment by accumulating most part of their net revenues as internal reserves. However if the internal reserves are accumulated too much, unemployment rate is not avoidable to increase because of the lack of companies' investment and decreased demand for labor. Moreover, if the accumulated capital is managed unproductively, like being put in a speculative financial and stock business that has small labor employment

6 Unemployment rate $=3.789+0.021$ (Growth rate)

$(8.83)(0.42) \mathrm{R}$ squa $=0.004$ d.f. $=51$

Unemployment rate change $=-0.098-0.088$ (Growth rate change)

$(-0.98)(-3.97) \mathrm{R}$ squa $=0.239$ d.f. $=50$

Average of unemployment rate and growth rate's variation are -0.0923 and 0.0635 respectively. 
effect, the economy becomes depressed further because of the over-supply state in the factor and product market.

ii. Lack of full employment strategy: trend of growth structure without employment

First, because of the development of capital intensive industries and production methods, the phenomenon of growth without employment becomes generalized globally. Growth without employment becomes a main cause of the expansion of the rich-poor gap and social conflict. The effect of economic development's employment expansion has also decreased in Korea. Thus the employment coefficient per output in the whole industry has declined by more than $30 \%$. The employment coefficient in electronic and electric equipment industries which are the main export industries in Korea declined significantly because of decreased localization ratio of production. In service industry, employment coefficient decreased by about $44 \%$ in social service and other services, therefore, the effect of the service industry to employment is decreasing even though its employment coefficient is large. Before the year 1975, large size companies played a main role in job creation. However, they are now occupying only $24.2 \%$ (in 2004) of job creation. Small businesses cannot supplement major companies' decreased ability of employment, and though the service industry can absorb part of it, its ability is reaching the limit. Nevertheless, due to the economic development policy focused on big companies, their share in domestic output rises to $51.1 \%$. Major companies' contribution to national total production decreased from $69.3 \%$ in 1975 to $51.1 \%$ in 2004. [4]

Second, employment opportunity for domestic laborer is more restricted and high unemployment rate is lasting in spite of economic growth not only because of structural problems associated with economic and technology development, but also because of the outflow of capital to low wage countries and inflow of low wage foreign labor following the opening of labor market and improvement of traffic and information,.

iii. Limit of macroeconomic policy ignoring social policy

1. Failure in job creation policy

In OECD countries, economic policy has been unsuccessful in reducing unemployment since the 1990's. This may be because policies to decrease unemployment were not active or never carried out practically. It seems to be also the result of expansion of universal welfare or provision of protection services to the disadvantaged for securing basic livelihood focused on just providing cash or service. In Korea, especially in 1998 when the serious financial crisis and mass unemployment occurred, the government pledged unemployment measures as priorities and invested huge budgets in positive labor policies. But the unemployment rate was lasting in high level. Therefore the policies to increase employment at that time are assessed to be unsuccessful.

2. Limit of macroeconomic policy

Keynes' aggregate demand management policy loses power in increasing the effect of employment. Schumpeter's innovation requires short-term policy because innovations are discontinuous, capital intensive, and take a long time to occur. Macro financial and monetary expansion without sophisticated plans might increase total demand raising chiefly prices because they have little effect on increasing the total supply. Thus, they are not effective at decreasing unemployment.

The effect of boosting investment and creating jobs is also small, depending on the policies of labor flexibility of neoliberalism or policies encouraging innovation of companies. The labor replacement effect due to capital migration to foreign countries and the development of technology in market seems to exceed the job creation effect by policies of government's total demand expansion or inducing company investment.

The excessive stress of market freedom has brought inevitable failure in attaining full employment and national happiness enhancement by victimizing social value to individual unrestricted freedom beyond the freedom function as a social ideal of the market. In addition, government used to lessen market's potentiality and its job creating ability by subordinating company and individual economic freedoms to dogmatic social value. Likewise, socialistic government intervention damages the advantage of the market autonomous decision principle.

3. Failure of integrated access to economic and social problems

Overcoming the failures of market and government in reaching full employment is difficult to be accomplished only with those policies pursuing economic efficiency and growth and supplementing their flaws. And it cannot be accomplished by social policy in which individual value is lightly considered by pursuit of dogmatic public value. Nevertheless, experts and policy makers in both parts used to cling to their own views. For example, the development strategy focused on big major companies without considering employment problems greatly has decreased the effect of employment. And the company avoidance of investment gets bigger and its effect of reducing unemployment becomes smaller, because of the limit of companies to overcome the problem of labor unions' strategies of maintaining exclusive high wages and employment and because of government policies that cannot control and persuade them.

This stems from a lack of theories and policies that approach economic and social problems comprehensively. Especially, a concept of social value in creating jobs is very weak. Despite continuous reflections on the faults of free market ideology, socialism, or social democracy has dominated our society since the industrial revolution, the society still has blind faiths in the free market and nationalism.

Supposing that the current global economy substantively depends on social democratic economies where government intervention enforces strongly the free market ideology, and also supposing that their intervention policies have failed or been unsuccessful, the third model in which citizens, not only market and government, participate directly is necessary. The third way should include changes in subjects of the economic 
and social systems, not changes in government policies.

\subsection{Limit of Contribution of Economic Growth to Enhancement of National Happiness Level}

\subsubsection{Economic Accomplishment and National Happiness Level}

The assumption that high economic growth rate owing to the autonomous economic mechanism enhances national happiness is supported by many people. The logic has also been criticized since long before, and thus interest in a national happiness index has increased continuously.

i. Relation between national happiness index (HPI) and per capita GDP

Efforts to evaluate the level of national happiness have continued. The UN releases human development index annually. The UN's Sustainable Development Solutions Networks (USDSN) sets 17 kinds of happiness goals and includes economical, social and political indices as evaluation criteria. When asked about those indices to 1000 people of each country, in 2015 Denmark was the first, and Switzerland second(the first in 2014), Sweden 10th, USA 13th, Japan 53th(46th in 2014), and Korea 58th(47th in 2014). The UN index includes not only economic development, economic results and other happiness elements. Therefore, unless economy proportionally enhances other human's happiness or economical results surpass other happiness indices, economic development and national happiness cannot be proportional in this index.

The universal happiness index is very difficult to be developed because every country and society must agree and because of the importance of other happiness elements beyond the economy. Hence, the results of appraisal are different according to rating institutions. For example, New Economic Foundation (NEF) in UK, economic results are not included. Life expectation, satisfaction with life and footprint of life are important there. In NEF, The ranking is in order of Costa Rica, Dominica, Guatemala, Vietnam, Colombia, Cuba, El Salvador, Brazil and Honduras. On the other hand, USA which has high economic achievement is 114th among 143 countries and the UK is 74th, Japan is 75th, Canada is 89th. Korea is 68th and China is 20th. [29]

Nevertheless, economic ability is important in livelihood, and so the UN's index seems to be more standard in such an aspect. Therefore, we compare the relation between two factors depending on the UN index.

ii. UN happiness index and economic level

The happiness index of the UN includes per capita GDP, social assistance, healthy life span, freedom of choice in life, generosity, corruption perceptions rate, dystopia and others. Looking at Table 2 and comparing the happiness index rank in the '2015 World Happiness Report' the UN released with per capita GDP statistics released in 2014 by the World Bank, the ranks of per capita GDP and happiness index do not show big differences in Europe excluding Luxemburg. In France, Germany, Iceland, USA, Australia and the others, the gap between the ranks of two indicators is more than 5 . However, the rank orders of the two are relatively close, compared to the other 158 countries. [28]

Table 2. Rank of Per Capita GDP and UN Happiness Index of Top 20 Countries (2014, US \$, Perfect Score 10 for happiness index).

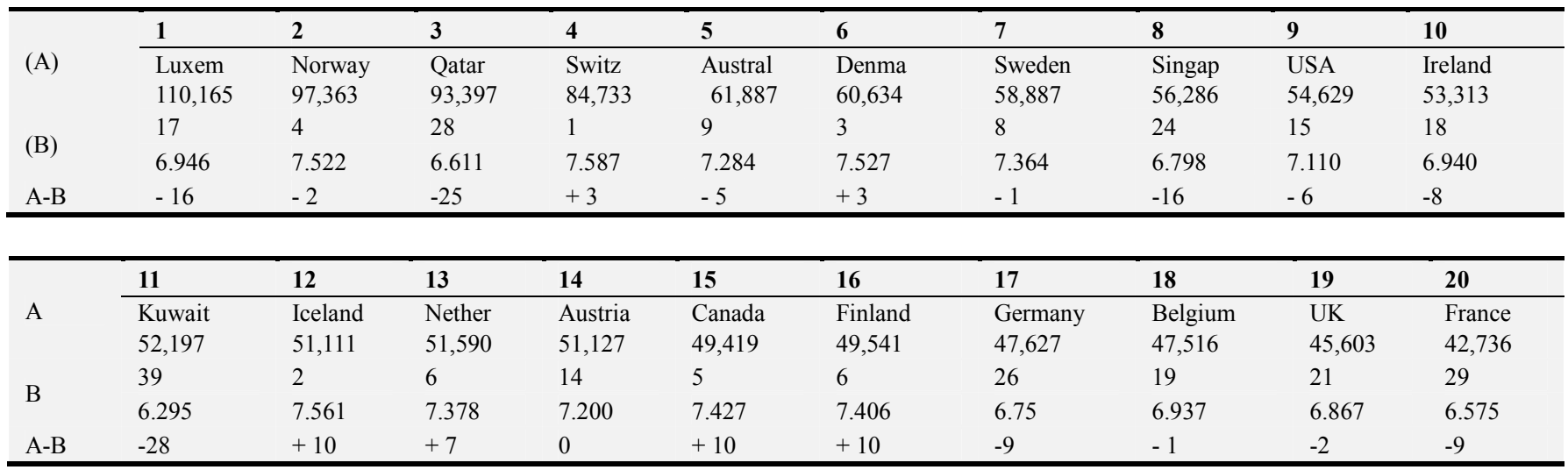

note 1: A is rank of per capita income $(\$)$. B is happiness rank \& scores

note 2: per capita GDP was released by the World Bank in 2014 and happiness index is average of the year 2012-2014 by UN.

note3: Luxem: Luxemburg, Switz: Switzerland, Austral: Australia, Denma: Denmark, Singap: Singapore, Nether: Netherlands.

Table 3. Per capita GDP and happiness index rankings of some interesting countries in 2014.

\begin{tabular}{|c|c|c|c|c|c|c|c|c|c|c|}
\hline & 28 & 25 & 23 & 26 & 79 & 32 & 22 & 60 & 64 & 67 \\
\hline A & $\begin{array}{l}\text { Korea } \\
27,971\end{array}$ & $\begin{array}{l}\text { Japan36,1 } \\
94\end{array}$ & $\begin{array}{l}\text { Hong } \\
40,122\end{array}$ & $\begin{array}{l}\text { Italia } \\
34,960\end{array}$ & $\begin{array}{l}\text { China } \\
7,594\end{array}$ & $\begin{array}{l}\text { Taiwan } \\
22,083\end{array}$ & $\begin{array}{l}\text { Newze } \\
42,409\end{array}$ & $\begin{array}{l}\text { Brazil } \\
11,612\end{array}$ & $\begin{array}{l}\text { Mexico } \\
10,361\end{array}$ & $\begin{array}{l}\text { Costa } \\
10,035\end{array}$ \\
\hline$D$ & 47 & 46 & 72 & 50 & 84 & 38 & 9 & 16 & 14 & 12 \\
\hline B & 5.984 & 5.987 & 5.474 & 5.948 & 5.140 & 6.298 & 7,286 & 6,983 & 7.187 & 7.187 \\
\hline A-B & -19 & -24 & -49 & -22 & -5 & -6 & +13 & +44 & +50 & +55 \\
\hline
\end{tabular}

Note 1: Hong: Hong Kong, Newze: New Zealand, Costa: Costa Rica

Note 2: Taiwan's per capita GDP comes from IMF statistics. 
If the contribution to happiness index scores of each element is analyzed making use of other analysis result $[19]^{7}$, as in Table 4, per capita GDP's contribution rate to the UN's happiness index is $4.3 \%$ higher in high income OECD countries than the average of 158 countries. Namely, the contribution of income level is relatively larger in wealthy countries than in low income countries. Per capita GDP's contribution rate in Korea reaches $59.1 \%$, showing that the happiness level depends more on the income level than in other OECD countries.

Table 4. UN Happiness Elements' Contribution Rate to Happiness Index (Unit, \%).

\begin{tabular}{llll}
\hline & World & OECD & Korea \\
\hline per capita GDP & $49.7(3.116)$ & $54.0(3.527)$ & $59.1(3.504)$ \\
social support & $29.3(1.839)$ & $32.3(2.112)$ & $31.0(1.839)$ \\
healthy life span & $28.8(1.807)$ & $31.2(2.041)$ & $35.8(2.121)$ \\
free choice of life & $12.2(0.763)$ & $12.9(0.844)$ & $11.3(0.672)$ \\
generosity & $0.0(-0.004)$ & $0.1(0.034)$ & $-0.87(-0.052)$ \\
corruption perception & $6.9(0.436)$ & $-5.7(-0,375)$ & $-8.0(-0.473)$ \\
constant & $-26.8(-1.68)$ & $-25.7(-1.68)$ & $-18.8(-1.68)$ \\
estimated value of HPI & $100.0(6.277)$ & $100(6.533)$ & $100(5.929)$ \\
\hline
\end{tabular}

note: The estimated value is different from actual value. The actual value of global average is 5.432 in 2015, which is much smaller than 6.277 of the estimation for the last decade. Korea's actual value is 5.780 in 2015, which is close to the estimation.

However, despite the high contribution rate of income level to the value of the happiness index, there are other great portion of national happiness which economic development cannot explain and several characteristic differences between the two appear in Table 2 and Table 3.

In some advanced countries of Europe, national happiness improves with economic development, taking into account that both factors change with small gaps between the ranks of two indices. But ranks of happiness level are higher than or similar to per capita GDP in only special countries of small populations and high per capita GDP. Canada, Finland, Iceland and New Zealand are countries with small population and abundant natural resources, showing much higher happiness index rankings than per capita GDP. Though nature is not included as a happiness element, it might influence other variables representing satisfaction with life.

In spite of higher per capita GDP, there are big gaps between the two ranks in southern European countries and non-European countries. Countries with huge population among advanced countries of Europe show low happiness rankings compared to per capita GDP. Population size can influence social conflict or quality of life. Furthermore, some countries have much lower happiness index rankings compared to per capita GDP. For instance, there are large

\footnotetext{
7 The result of regression analysis 156 countries' happiness indices to explanatory variables is below.

Happiness index $=-1.68+0.338(\log ($ per capita GDP $))+2.334($ social support $)+$ 0.029 (healthy expected life span in birth) +1.056 (free choice of life) + 0.820 (generosity) - 0.579 (corruption perception)

(note) Corruption Perception have meaning in 5\%, other variables in $1 \%$. $\mathrm{N}=1,118$ Adj. $\mathrm{R}$ squared $=0.738$
}

negative gaps in Hong Kong (-49), Qatar(-25), Japan(-24), Kuwait(-28), Italy(-22), Korea(-19) and Singapore(-16) as in shown Table 3.

On the contrary, South American countries and countries of an abundance of nature have extremely high happiness index rankings compared to per capita GDP level. For example, Costa Rica shows that economic level doesn't matter with human happiness because it's per capita GDP is 67 th while Happiness index is 12th in UN index and 1st in the assessment by NEF. Mexico, Brazil and others also show much higher happiness index rankings compared to per capita GDP level.

The limit of UN happiness estimation standard appears not to be little. The UN happiness index's strong dependence on per capita GDP can be recognized by the correlation rate of 0.777 at $1 \%$ significant level.

Per capita GDP and health life expectancy are also highly correlated among happiness elements of UN. ${ }^{8}$ Therefore, it is supposed that the influence of economic level to happiness index is almost absolute, because the contribution rates of these three elements occupy the largest part in Table 4.

However, when comparing per capita GDP and happiness index for the last decade, unless satisfaction with other life indicators does not improve simultaneously with economic development, the difference between two indices is unavoidable. Therefore it is difficult to argue that economic growth increases national happiness proportionally and automatically. However it can be said that in countries which have been developed for a long time and have reformed society with an awareness of happiness, economic development has generally enhanced happiness.

\subsubsection{Elements Omitted in UN National Happiness and Importance of Employment}

The psychological judgment of individual happiness in UN index omits objective and social elements expected to influence it. And the UN happiness index also excludes several important happiness elements, including healthy household, work, social relationships, and mental satisfaction. However, national happiness as a social indicator has to represent social life problems occurred in the process of economic development. The OECD indicator includes comprehensive social factors such as income distribution and social integration index. There are also differences in the level of influence to national happiness among indices, but current indices do not reflect this due to the difficulties weighting the different importance. Especially, labor is extremely important in deciding national happiness among indices of direct influence.

i. Labor as the basis of individual happiness

First, the desire to work is a major value of human existence. Therefore, a proper level of work is an essential

8 Correlation between per capita GDP and social support is showing 0.046, and 0.832 for life span. Life choice or corruption perception show significant estimation in $1 \%$ level but the correlation are very small as 0.359 and 0.336 each, generosity has 0 value. 
element of happiness.

Second, labor can influence significantly other factors as education, dwelling, health, household and social relationship. In the same age cohort, workers used to be more educated, healthier and in better housing conditions than unemployed individuals due to steady and higher income. For example, when dividing urban households into the whole households and worker households, the percentage of college graduated households among whole households was $32.4 \%$ but worker household was 36.3\% in 1996 in Korea and 35.3\% and 39.7\% in 1999 respectively. [11] Also looking at disease, workers who experienced stroke is $1.85 \%$ compared to $18.47 \%$ of the unemployed in 1998 , it was $1.61 \%$ when the percentage of the latter was $7.34 \%$ in 2005 . [20] Workers who practiced health examination were 0.43 compared to 0.25 of the unemployed group. [20]

Third, psychological stability owing to labor affects largely various living factors including family and social human relationship. The loss of work weakens family structures. In worker households, the mother and child family ratio is $2.1 \%$ but in whole households, it is $3.1 \%$. [11] Therefore, workers' family relationship might be more stable. In comparison, the employed household's dissatisfaction rate with general family life is $7.8 \%$, and unemployed household's rate reaches at $19.7 \%$. Also dissatisfaction rates of their accomplishment in life show gaps as large as 19.5\% and $30.6 \%$ each. [3] Employed households' social relationships would be more amicable than the unemployed because dissatisfaction rates in family culture and leisure activity show big gaps as large as $2.7 \%$ and $40.2 \%$ respectively. [3]

ii. Individual labor also increases the happiness of other people.

First, individual instability caused by unemployment would harm other's happiness by increasing social discomfort. Second, on the other hand, his stable life owing to employment would increase national happiness by improving the quality of labor and products. Third, individual labor can enhance others' happiness by providing good service especially for the disadvantaged. Therefore, labor is a chief way of producing social value in addition to economic value. The production of economic and social value through work not only enhances national happiness but also increases one's own happiness by meeting desires to work and receiving social compensation.

iii. Labor is the most effective way to decrease poverty and improve distribution

The income ratio of top $10 \%$ to the bottom $10 \%$ is estimated to decrease by 0.115 when the growth rate is $1 \%$. However, it is estimated that a $1 \%$ decrease of unemployment rate reduces the ratio by 0.417 . [13] Additionally, individual unemployment affects significantly poverty. [10]

In this sense, there is an important difference between the market value of labor which tells labor's creation of national material wealth and the social value of labor that includes individual happiness and the value of affecting family and society. Moreover, if society's purpose is to attain national happiness, the participation of low income groups and the disadvantaged in labor is really important because marginal utility of their income and activity is higher.

\section{Balanced Development Model Through Cyclical Full Employment and National Happiness Enhancement [14]}

To attain national happiness and full employment, a model is necessary which increases national happiness by completely using social resources like labor and capital. A balanced development model can be an alternative, in which the economy and society can make full use of labor and capital in circulation. Full usage of labor and capital increases not only social value but also becomes a way of solving economic depression and unemployment problems.

\subsection{Civilization of Subject and Structure of Creating National Happiness}

A subject which has to correct failures of market and government cannot be only the government and the market which are culprits of the failure. Because individuals are the ultimate subjects and decision makers of happiness, they should be another subjects in correcting the failure, and they are guaranteed to do it freely with independence.

\subsubsection{Shrink of Citizens' Sovereignty Caused by Excessive of Power of Market and Government}

National happiness is composed of economic or noneconomic element. In modern society, economic or noneconomic national happiness is created mostly by market activity. However, sometimes citizens as well as government create both types of happiness by themselves. The roles of the three subjects are changing according to society, but the market is the main subject to create it.

i. Decrease in creating national happiness function of market due to monopolized economic power

Market creates many economic values of various materials and services which occupy a very large portion of national happiness. In recent history, as shown in UN Happiness index statistic, liberalist markets play an important role in national happiness because income level is very important to human happiness. Also human's happiness or satisfaction becomes greater when gained by individuals' free choice than when distributed forcibly. In this context, the liberalistic market system contributes to enhancement of happiness more than the socialist system.

Market failure to create maximum national happiness is caused by imperfect competition in which the market does not function correctly due to control by the monopoly powers of capital, labor and government. The labor market is also monopolized in large industries such as automobiles, ships, electronics, and many others in Korea. Labor unions in such industries have aggravated wage disparity between organized 
workers and unorganized ones and between small and large industries, distorting the market function and socio-economic policies.

ii. Decrease in government's function due to excessively big politic power

Because of market failure or non-market value, the public value of which government should be responsible in contributing to national happiness is substantial, and such a value has recovered by government policies. Government has to solve economic and social problems to stabilize society and enhance social solidarity value, and it also has the responsibility of correcting economic and social failures in order to satisfy human's material or non-material selfless desires that cannot be got in the market. Therefore, the purpose of government policies is to realize public value by eliminating obstacles constricting altruism, human's natural value in addition to traditional values such as economic efficiency, social stability and ideology of solidarity.

For example, first, because unemployment, poverty and distribution are the results of market failures, they are the main area of traditional economic and social policies. Second, one of the greatest uneconomic human happiness is relationship with family and neighbors. However, there are also psychological elements influenced by economic elements. Government has tried to solve this not only through economic policy but also social policy. Third, human's happiness is created in a relationship with the environment. This cannot be created in the market and so it is the responsibility of the government.

Market failures and unmet social happiness have been considered as the function government can handle for a long time. In the social democracy systems on which most advanced countries depend, the increase of government function has been stressed and government's role in distribution has been justified and increased for long time. But there are still substantial parts of national happiness in which governments have failed to provide. Especially both politicians' over issue of promises based on populism and market regulations increased by the administration are illustrating nation's selfish activity.

iii. Recovery of civil right through civil social participation

Because happiness is diminished by the selfish activity of markets, organized civil bodies and government, civilians who are victims and also subjects of happiness should participate in creating national happiness to recover civil rights by replacing some functions of markets and governments.

This is also a niche area that the market and nation cannot reach. The magnitude might be different according to individual, country, and psychological states. There remain quite considerable economic needs never fulfilled because of chronic unemployment, poverty, lack of medical, educational, dwelling, human service to the disadvantaged, and because of high prices of markets or geographical and institutional exclusion. There are also uneconomic demands which are not supplied in markets and unfulfilled by government. Thus, civilians need to supply those themselves. And individuals' altruistic desires can be better fulfilled by themselves. Such desires can be created by government, society, religion bodies, and even by individual psychological attitudes. To illustrate more clearly, it can be systematized as follows.

\subsubsection{Structure and Subject of National Happiness or Gross Wellbeing Creation}

i. Structure of Gross Wellbeing Creation

Gross wellbeing is composed of economic gross wellbeing and social gross wellbeing.

$$
\mathrm{GW}=\mathrm{EGW}+\mathrm{SGW}
$$

GW means gross national wellbeing and EGW means economic gross wellbeing. SGW (social gross wellbeing) is composed of happiness from economic activity like labor (L), distribution(Di), poverty(Pv) and the happiness from social activity such as family(Fa), neighborhood(Ne), social relationships(So) and environment(En).

$$
\mathrm{SGW}=\mathrm{F}(\mathrm{E}(\mathrm{L}, \mathrm{Di}, \mathrm{Pv}), \mathrm{S}(\mathrm{Fa}, \mathrm{Ne}, \mathrm{So}, \mathrm{En}))
$$

The material satisfaction of GW created in markets is substantial in modern society. However, other material desire and social desire can be fulfilled by government or cooperation between government and civil society.

Another element composing GW is psychological desire. Individual psychological desire is decided by individual effort. Psychological satisfaction mutually influences material and uneconomic happiness. However there is also independent satisfaction. P. Samuelson introduced psychological elements in the concept of happiness as increasing happiness by reducing desire. $[15,26]$ But in this paper, happiness supposes the existence of the psychological satisfaction is independent of social and material desires. It highlights that the happiness' circle is expanded when psychological desires are accomplished additionally besides material and social desire. Non-material satisfaction like leisure can be naturally helpful in the expansion of psychological desire.

Therefore, GW is composed of four elements according to subjects of creation. Figure 1 consists of ' $\mathrm{M}$ ', ' $\mathrm{G}$ ', and ' $\mathrm{P}$ ' representing respectively market, government, and civil society, namely, the third subject of state management, and 'I' representing individual psychological decisions. The circle indicates the greatest happiness state(bliss or nirvana's state), and the square is the maximum happiness that can be accomplished by a liberalist market system and intervention of government and civil society. 'I', the happiness between the square and the circle has to be accomplished by individual effort and responsibility. That is,

$$
\mathrm{GW}=\mathrm{I}+\mathrm{M}+(\mathrm{G}+\mathrm{P})
$$

'M', 'G', 'P', and 'I' can contribute to increasing GW independently and additionally. When one of those parts has problems reducing happiness, the other parts have to supplement this reduction, and thus national welfare and GW 
level should be equal in the short run or statically. In the long run, one part or various parts can extensively expand GW outside the circle and total GW can increase.

' $\mathrm{P}$ ' is the area which can be accomplished by civilians independently or with cooperation with government, but there are ' $\mathrm{B}$ ' the area which is not accomplished. ' $\mathrm{G}$ ' is the area accomplished by only government but there are ' $\mathrm{C}$ ' the area left by the government's lack of effort or failure. 'B' and ' $\mathrm{C}$ ' are the areas which should have to be accomplished by government and civil correction of market failures.

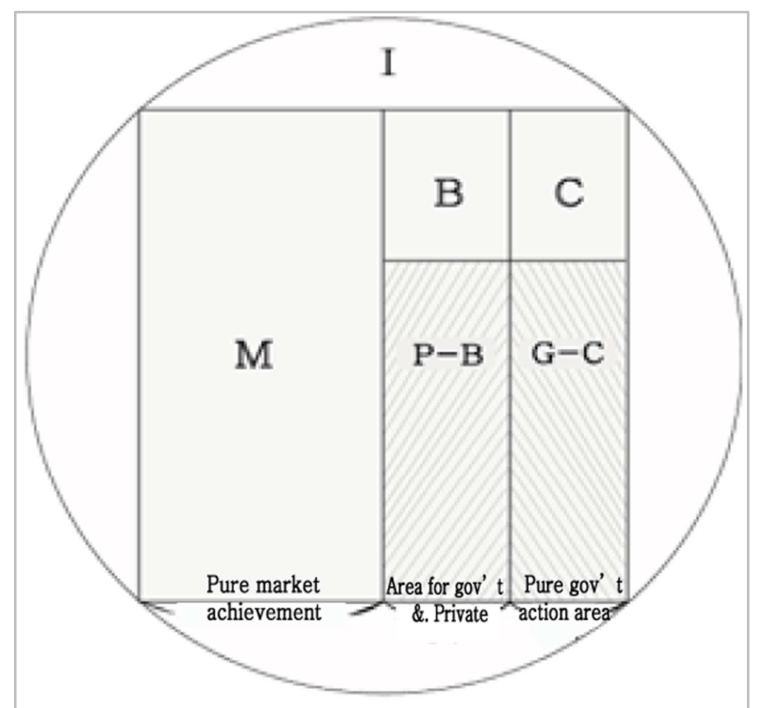

Figure 1. Accomplishment and Failure of Market and Government Description.

ii. Relation among three subjects; market, government and civic group

The civil role is needed in addition to market and government. The division of roles between government and civilians is distinguished in creating deficient economic and social values. First, the value that the market never creates (market's creation ability $=0$ ) can be created by government or selfless civilians. Second, the value that market can create insufficiently because of consumer's lack of purchasing power, which means $0<$ market's creation ability or purchasing power of consumers $<$ market price, can be generated by civilians or prosecuted under government support. This is a model of accomplishing full employment and enhancing GW simultaneously by increasing the social value owing to enabling civilians participate in creating main values in the process of accomplishing full employment. Because it is realistic to assume failures of market and government, ' $\mathrm{P}$ ' and ' $\mathrm{G}$ ' of happiness have to be created by civilians and government independently, but the magnitude of 'B' and ' $\mathrm{C}$ ' will be measured by an assessment about the current economic system. The more critical is the role of market or government, the larger area is ' $\mathrm{B}$ ' or/and ' $\mathrm{C}$ '.

To enhance GW by taking action against the economic and social failures of both the market and government, civil society should also adjust its role in the process of business cycle to prevent reduction of national happiness as early as possible

\subsection{Balanced Development Model of Cyclical Full Employment}

\subsubsection{Structure of Circular Balance of Full Employment $[13]^{9}$}

To correct market failures, government and civil society can use workers abandoned by the market and excessively accumulated capital in creating social value. ${ }^{10}$ The ultimate purpose of this model is to make full use of society's surplus resources and contribute to the enhancement of GNP as well as GW. In this sense, full usage of production resources maximizes GW.

$$
\mathrm{GW}=\mathrm{I}+\mathrm{M}(\mathrm{Lm}, \mathrm{Km})+(\mathrm{G}(\mathrm{Lg}, \mathrm{Kg})+\mathrm{P}(\mathrm{Lp}, \mathrm{Kp}))
$$

Therefore, resources should be fully used in this model, and thus the identical equation $\overline{\mathrm{L}}=\mathrm{Lm}+\mathrm{Lg}+\mathrm{Lp}$ and $\overline{\mathrm{K}}=\mathrm{Km}$ $+\mathrm{Kg}+\mathrm{Kp}$ are established where $\overline{\mathrm{L}}$ and $\overline{\mathrm{K}}$ are the endowment of labor and capital to the society and where subscripts $\mathrm{m}, \mathrm{g}$, and $\mathrm{p}$ denote market, government and private respectively. Therefore, the circular model also means circular use of resources. It aims at full usage of labor and capital and also aims to accomplish circular balance through recycling renewable resources.

In the cycling process, when depressed, government and civil society accomplish the maintenance of full employment and enhancement of GW by using surplus labor and capital in creation of social benefit. When prosperous, labor and capital have to move to the market to increase GNP and maintain full employment.

Excessively accumulated capital in depression could contribute to the increase of GW by hiring unemployed labor and creating economic and social value through government's price, monetary, and financial policies or civilians' participation in the production of such values. Therefore, by creating economic and social value with the cyclical usage of the surplus labor and capital, ${ }^{11}$ society would realizes the mechanism that accomplishes the balances in both the production factor and product market, and also acquire the balance between society and economy. For the consumption of newly produced value, the model suggests the ordinary income group pay the price according their ability and the benefit principle and to induce all vulnerable groups to consume with financial support.

\subsubsection{Guaranteeing Basic Life in Cyclical Balanced Employment Model}

One of the largest causes of market economy's depression

\footnotetext{
9 Balance allows just a small difference between economy and social development. In the text, for example, if differences between the rankings of income and happiness are less than five rankings apart, it indicates a relatively balanced development. Because a simultaneous development of the economy and society is generally unrealistic, social development can rightly follow economic development, and economic development may occur after social development.

${ }^{10}$ Surplus labor and capital's accumulation will sustain economic depression due to lack of total demand.

${ }^{11}$ Surplus capital and labor can be of course used to create new industries.
} 
is a lack of purchasing power due to excessive capital accumulation. [7] ${ }^{12}$ Excessive capital in the market could be mobilized to extend basic livelihood security having high social value, to improve the quality of national life, enhancing GW. Because of maintenance and increase of disparity between the rich and poor in the process of economic development and capital accumulation, the potential consumers always lack purchasing power and thus basic consumption, and this generates social and distribution problems and constricts the realization of potential GW. The supplementation of basic consumption shortages is not just the transfer of basic income. It is the primary investment target which could be solved by full employment. Government and civil society induce business to invest in market with surplus capital by order of importance, for example, necessities of life, medical, education and antipoverty, and market failures can be corrected with these policies. That is, some part of excessively accumulated capital can be induced to be invested in public programs by government mediation to accomplish full employment.

In this circulated and balanced development process, a society could be attained where civilians live comfortably because the government and civil society guarantee the whole nation's basic life maintenance, the elimination of poverty, reasonable distribution, the improvement of family and social relationship, and the environmental improvement. The model also contributes to the economic purposes of increasing GNP owing to solving various failures such as excessive accumulation of capital, and the continuous pressure of unemployment. It can also contribute to expansion of GW creation circle, creating and developing a society with stabilized individual life.

\section{Restoration of Market's and Government's Public Logic, and Strategy Increasing Civil Society's Role}

Markets constrict increases of GW because of too selfish liberalism. The excessive regulation by nationalism also constricts GW by reducing market efficiency. The restriction of free activity in the market is mostly the result from regulations due to government convenience and economic policies ensuring the maintenance and increase of monopolies due to collusion between power and wealth. On

\footnotetext{
12 Marx and Piketti mainly argued that because capital accumulation of liberalistic economy drops profit rate and its result of not finding investment market, logical change to communism or increase of wealth tax is necessary. According to John A. Hobson and Clifford Douglas, under-consumption, in 192030 's was ascribed to lack of consumption due to excessive accumulation of capital during global depression. However Douglas sought full employment policy to develop into economic collapse due to inflation or war of exporting excessive product (ibid, p.46), and he argued to build a national investment company (e.g. England), and to manage the increased national production ability, distribute it to all nation, general stockholder, and then argued that the saved labor could be used in psychological and cultural creation.
}

the other hand, public value is not accomplished by government because of failures in social policy caused by the political populism and government bureaucracy.

Therefore, as subjects of society, civilians have to strengthen their social roles and participate in state management directly in order to recover their right. Civil society should have a system that allows members to supervise the market and government with independent authority which enables civilians to do freely economic and social activity.

\subsection{Normalization of Market Function}

Institutional adjustment is necessary for production factors to move freely and smoothly in competitive markets. To allow labor and capital to move freely among the economic activities of the three subjects, perfect competition in market should be secured. And monopolistic and inelastic behaviors of government and civil social groups must be eliminated. Free economic activity which guarantees autonomous decision and competition should be possible in the market, and the increase or maximization of market efficiency increases or maximizes liberalistic GW. In Korea, the medical service market is restricted and distorted by government regulations such as artificially determined prices in a fee-for-service system and the civil body's norm of equivalent medical services for all classes. Small start-up companies are frequently collapsed because large industries imitate their new technologies and destroy their efforts to invent new items and technologies. Auto industries have to pay higher wages than other related industries under the pressure of the strong labor unions. The unions constrain the new entries of lower wage workers into industries preventing the use of surplus labor and capital.

\subsubsection{Switching of the Current Positive Regulation Against the Market to Negative Regulation ${ }^{13}$}

To induce inactive capital accumulated by reinforced market regulations and companies' greedy interest into the productive investments in the market, the autonomy of market functions should be reinforced in the first time. Irrational regulations against liberalistic activity that are based on human nature must be eliminated. Positive regulations must be decreased which become the main cause of easy administration and corruption and collusive links between politicians and business men. Regulation against civil economic activity should be comprehensive and thus should not constrict other activities excluding necessary prohibition. All regulation policies constricting the free activities of economic subjects in the market must regulate only those activities that must be prohibited for the public interest. Problems other than regulation have to be controlled

\footnotetext{
${ }^{13}$ The government policies supposed in this paper are proposed as comprehensive ways. Therefore, their increasing effect of employment has to be proven and specified. According to the evidence, a concrete direction or size of policy and codification among policies can be possible, and so multiple in-depth empirical studies must follow.
} 
by assessments of public institutes. The violation of law and damage of public interest in the market could be supervised and adjusted through positive participation by government and civil society.

\subsubsection{Labor Substitution Tax Against Companies' Curtailment of Employment and Disturbance Tax or Additional Wage Income Tax Against Excessive Labor Power}

Current excessive state of labor supply in the market occurs because of companies' decreased employment due to the preference for capital intensive technology and due to the restriction of labor market entry by greedy monopoly of labor unions and expert groups such as doctors and lawyers. If it is difficult to remove the excessive power in order to reinforce the social responsibility of major companies, monopolistic labor, and collective job powers, price and tax policies that can lower entrance barriers into the market could be designed by eliminating monopolistic rent. First, a labor substitution tax could be introduced to compensate for the social cost incurred because chief companies reduce employment to raise profits. Second, additional income tax has to be institutionalized on high income gained from the monopoly of labor and job markets. In case of the latter, a taxation of penalty form against disturbance of labor entry is also possible. Therefore, unemployment decreases by increasing liberalization through relaxing monopolized power in the market by companies, labor or professional job groups and thus by increasing labor demand up to supply level. And all laborers are induced to share total wage income through rising employment.

Funds collected from the tax imposed on profits that large companies gain from choosing labor saving production are used in employment for the creation of social convenience. Also an additional wage income tax imposed on monopolistic labor and professional markets that restrict the entry of labor into the market induces a breakdown of labor market monopoly. And collected tax revenues support nonmonopolistic market companies which could absorb excluded labor. Through this process, unemployment could be eliminated or decreased by the comprehensive policies of price and taxation that make labor's total demand equal to total supply, accompanying the effect of reducing income disparity and increasing employment.

In the difficult condition to impose punitive taxation against capitalists' evading investment or laborers' evading labor, price support policies inducing them to participate in the production of material or social value are necessary by guaranteeing their labor income and business profits. Through appropriate reward to labor and capital which do not evade active behavior in the market, more resources could be used.

\subsection{Expansion of Employment Through Recovery of Government's Public Function}

Government and politics should recover public function. Government has to increase market efficiency when the freedom of the market fails, and must also create unmet social values. However, many bureaucrats and politicians in charge of this role have grown away from their original role and suppressed market and civil freedoms with monopolistic control. Therefore their controls must shrink to the range which does not harm economic and social policies, and then the market and society's function becomes efficient and public value would be maximized. Government employment policies to recover public function would be various. The enhancement of GW through public function could not be the same as GW through market activity. That is, in the happiness creation function, the natures of the market, government and civilians must be different because they have very different purposes; the pursuit of individual interest versus the pursuit of public interest.

\subsubsection{Production Systems of Employment Maximization Enabling Gross Wellbeing [9]}

Government's direct participation in business is necessary when the project generates large social benefits but private businessman cannot keep or promote it due to suppression of cost. In the production of lost social value and insufficient production and supply of merit goods in the market, government has to choose employment-centric strategies. Thus, first, the GWP concept should be chosen instead of GDP criteria in a selection of government programs. Examples of lost social values and deficient market supplies include deficiency of services for children and the elderly, insufficient basic livelihood services for low income and vulnerable groups, destruction of the environment, traffic congestion, degeneration of society and living conditions in overcrowded cities, and scarce populations in rural cities. The increases of these services' supply and employment would contribute to improving GW and GNP. Regarding the phenomena of replacing jobs by machines caused by the influence of technological changes, many economists including Michael Spence have highlighted the importance of public investments to basic social services such as education, medical services, and age security. [16, 23] And the assessment on the activities of governments and civil groups has to change to an assessment system maximizing public interest emphasizing more efficiency. Evaluation agents must also be replaced by suitable experts.

\subsubsection{Innovation of Public Investment Projects and Social Enterprises Focusing on Employment Increase}

Until now, because government programs enhancing $\mathrm{GW}$ used to be trusted to private companies, they are generated because of company's management of profit maximizing choice of technology. However, GW might increase further if governments choose technologies which create more jobs. And companies entrusted with government projects have to choose strategies maximizing employment, not the efficiency. Thus, even in large public projects in which civil society's participation is difficult, governments could choose ways that expand employment-increasing services. Governments could select small businesses or public corporations which are able to achieve the same production with the same budget as the 
entrusted private businesses. Private companies cannot avoid choosing labor-saving methods due to the suppression of labor unions and the costs of administration and management. However, in public businesses, governments must choose companies of increasing employment and ways of managements which do not such social costs.

For example, among various huge national projects in Korea, the four big river refurbishment projects could select employment-increasing technologies and methods through small businesses rather than major construction companies depending on machines.

\subsubsection{Monetary and Fiscal Policies to Induce Companies' Spontaneous Participation in Producing GW}

The excessive surplus of capital beyond the level of need for technological innovation makes total production exceed total demand, therefore depressing the economy and constricting demand for labor. The following methods might induce excessively accumulated capital into increasing demand for labor and GWP.

First, wealthy tax could be raised to financial assets against companies that have excessively accumulated funds including a punitive tax on capital reservation, and governments could sell public bonds to companies which are enforced to buy them with their excessively reserved profits or borrow companies' bank fund. Then these funds are invested in social value creation projects directly or the companies are stimulated to do it indirectly through financing to private enterprises. However, in boom season, there must be ways of returning the borrowed funds to companies such as through purchasing government bonds owned by companies in order to do private business by returning the company's fund.

Second, to induce the spontaneous participation of companies and individuals in projects increasing employment, innovation in government public investment policies is needed, such as policies guaranteeing investment value. In order to utilize inactive capitals toward creation of $\mathrm{GW}$, firstly, governments and private enterprises conjunctionally invest companies' accumulated inactive capital not only in growth strategy industries but also in GW creation business by compensating lost funds. The company's participation in production of public value could be attracted by the government's guarantee of price to the level of public value. However, as the condition for such favors, priority is given to companies that propose ways to increase employment, thus increasing the production of public value in the market. Secondly, governments and companies can make plans to use inactive capital by composing their conference organizations to eliminate each company's fear of losing money. Then they reduce each company's investment risk and contribute to social development. Thirdly, to collect invested money in GW creation, beneficiaries have to pay the price in the long term following the benefit pricing principle.

Third, traditional financial policies must change. Government monetary policy should not be the simple spread of money that has been used since Keynes' theory, but it should be structural policies meeting the public value. The main monetary policies of government has to focus on enhancing public value such as economic values like employment, removing poverty, improving distribution, and increasing the values of social stabilization and integration through improvement of family and social relationships and fulfillment of the individual selflessness, in addition to price stabilization or economic development. For example, the currency must be issued to support the maintenance of employment, and low income laborers' consumption of unmet livelihood desires. It must be mobilized in investment of public business to increasing employment beyond Keynesian aggregate demand management and classical market neutral theories. With this policy, demand and supply could be balanced in the labor and capital market.

\subsection{Strengthening Civilians' Economic and Social Roles [18]}

Civil society has no choice but to correct the market and government's failures when facing the realities of excessive selfishness in the market and misuse of power by government Civilians are the owners of markets and governments, and therefore must directly adjust failed agents and amend the inefficiency and corruption of both subjects.

The phenomenon that a civil society is inclined to change into another power group once it is organized, must be corrected by both government and markets. ${ }^{14}$ Therefore the three must control mutually and correct each other. With independence of a bureaucratized and empowered administration, legislation and jurisdiction institute, the civil society should participate in the correction process without producing adverse effects on the functions of markets and government.

Social enterprises are the main part of civil society's role to correct market and government failures. ${ }^{15}$ This starts from the supposition that the enhancement effect of national happiness is very deficient only with American private companies and individual donations that depend mainly on the free market ideology. And it comes from the assumption that the effects of job creation and increased social services accomplished through the government's direct intervention in some European have not been successful.

In the process, social companies in public projects have to discover ways to expand employment, overcoming corruption, prevent excessive profits and remove easy going management. If the government cannot do it, the public projects should be trusted to social companies.

\footnotetext{
14 Historically, there are no small failure experiences due to civilians' participation in government business, thus social companies should be prosecuted considering this harmful effect.

${ }^{15}$ In light of backgrounds of social companies, Europe attempted to create employment through positive employment policies in high unemployment societies, for example in response to the global depression of the 1970's and against neo liberalistic approaches such as privatization in the USA and the UK. This social economic concept in Europe especially before the industrial revolution in France and other countries highlights the community spirit which reinforces government's market intervention.
} 
It might be more effective to entrust public projects that can be done in labor intensive ways to social companies rather than commercial enterprises. For example, building and remodeling public medical facilities, house improvement, educational facility, welfare facilities that provide basic livelihood services can be trusted to social enterprises without premise of profits. Also, civil society can participate in cleaning, vocational training, and employment mediation which governments are doing on their own and in which private institutions are not willing to participate due to excessive government assessment. Thus, the promotion of such projects would be managed by civil society and private organizations to correct the failures of government while the government just supports financial part.

\section{Conclusion}

The full employment and happiness of the people are the most important goals of the society because labor is a crucial factor of individual happiness. The attainment of two objects is not successful in any economic policy and social security system of the liberalism, the socialism and the social democracy. This paper analyzes empirically the failures to achieve full employment and national happiness promotion despite long-term economic development with OECD and Korean statistics for the unemployment incidence and growth rate of income and UN happiness index.

The surplus of capital is emphasized as the cause of chronic unemployment and failure of enhancing national happiness. And the excessive capital is accumulated in the process of preferring labor saving methods and technologies to increase business profit in the monopolized markets and due to the bureaucratized administration and populism of the politics. Full usage of capital is necessary to get the full employment and enhance the national happiness.

Policy directions and several measures are also provided to enable the model to be applied in Korea. Civil society, including social enterprise, is stressed to correct the market and government's failures when facing the realities of excessive selfishness in the market and misuse of power by government. And the switch of the positive market regulation to the negative regulation is very important due to excessive intervention to increase the market efficiency in the market of the administration and political power in Korea. The punitive taxation are also suggested to the business choices of labor saving methods and the labor unions' rent wages by monopolizing labor markets to strengthen market competition. The government projects which are entrusted to the large businesses must be transferred to the civil bodies or small firms that could employ more workers producing equivalent output with the same budget, and such policies are very important especially in producing unmet social values in public health, education, housing services and environment.

This paper focuses on two important values, full employment and maximization of national happiness, but it includes social value as well as economic value in a model that would reduce a strict theoretical approach. More researches are also needed for the model to become a complete theoretical structure and to be practically implemented in real policies.

\section{References}

[1] Ko, Kyung Whan etc., Social Expenditure of Korea based in 2013, Korea Institute of Health and Social Affairs, policy paper 2014-83, page 212-218.

[2] E. F. Schmacher (translated by Kim Jeoung Woo), Small is Beautiful; Economics As If People Mattered, 1988, Dae Won Jung Sa.

[3] Kim, Seung Kwon, Kim Yoo Kyung etc., The 2009 National Survey on Fertility, Family Health and Welfare in Korea, research paper 2009-33, Korea Institute of Health and Social Affairs, p. 341 (table 10-26) \& p. 340 (table 10-25), pp. 337-9 (table 10-22), (table 10-23), \& (table 10-24).

[4] Kim, Seung Taek, Shin Yong Sang etc, A Study on Employment Strategy to Create Workplaces - 2008 Employment Strategy Study, 2007, Korea Labor Institute. page 24 (Chart II-2) and page 71 (Chart IV-2).

[5] Kim, Hae Won, Park Chan Im, Hwang Duk Soon, A Empirical Study on Creation of Employment in the 3rd sector, Korea Labor Institute, 2008.

[6] Kim, Hae Won, Is the Social Enterprise Sustainable in Social Service? Labor Review, Korea Labor Institute, 2007.

[7] Clifford H. Douglas (Translated by Lee Seung Hyun), Social Credit: Why is Basic Income necessary?, Yeuk Sa co., April 2016, p. 97 , p. $173 \&$ p. 117.

[8] Park, Se Kyung etc., A Study on Growth Possibility of Social Service as Industry, 2014, Korea Institute of Health and Social Affairs, 14-12.

[9] Bark, Soon Il, Choice of Technology and Employment, 1975, M. A. dissertation of graduate school of Seoul National University.

[10] Bark, Soon Il etc., The Analysis of Impoverishment Factors in Korea and Policy Direction, Korea Institute of Health and Social Affairs, 1993, p. 90 (table 41).

[11] Bark, Soon Il, Choi Hyun Soo etc., The Analysis on Causes of Expansion of Disparity between Rich and Poor and Policy Measures for the poor and under middle Class, Policy Paper 2000-14, Korea Institute of Health and Social Affairs, p. 47 (table II-3), p. 68 (table II-16).

[12] Bark, Soon Il, Worsening Income Distribution After the Economic Crisis And Policy Recommendations, presented paper in the conference of Social Policy in Asia Pacific Region.

[13] Bark, Soon Il, What is the End of Welfare Competition? A Opportunity for new Welfare Society? or A Prelude for a New Conflict Period? - Cyclical Balanced Development Model of Economy and Society, e-book 21, 2012, p. 77.

[14] Bark Soon Il, A cyclical Equilibrating Development of Economy and SDociety of Enhancing National Happiness and Full Employment, pages 1-44, Journal of Korean Economic Development, Vol.23, No. 1, March 2017. 
[15] Yoo, Keun Choon etc., A Study on Fusion of Welfare and Technology, 2014-2, Korea Institute of Health and social Affairs, pp. 37-38.

[16] Ryu, Chon Il, "The Future of Capitalist Market Economy", World Economy and Korea Economy in Risk, a seminar paper March 2016, Seoul Institute of Society and Economy.

[17] Yoon, Jeoun Hyang, Realities of Creation of Social Work places and Measures for Improvement, Korea Institute of Employment Information, 2007.

[18] Jeon, Byung You, Park, Chan Im, Whang, Duk Soon etc., A Study on Creation of Social Work places, Korea Labor Institute, 2003.

[19] Jeong, Hae Sik and Kim, Seong A, The Quality of Life Korea in view of OECD BLI Indicators, Health Welfare Forum, Sep. 2015, Korea Institute of Health and Social Affairs.

[20] The Head Quarter of Health Management \& Korea Institute of Health and Social Affairs, National Health Survey, the Third (2005) In depth Study - Parts of Health Interview and Health consciousness, 2007, p. 100 (table 5), p. 323 (table 6).

[21] Korea Institute of Health and Social Affairs \& Korea Labor
Institute, A Report of Survey on Realities of Unemployment and Welfare, Apr. 1999.

[22] Hong, Seok Pyo \& Bark, Soon Il etc., A Study on Improving System for Financial Effectiveness Through Social Safety Net, research paper 2002-13, Korea Institute of Health and Social Affairs.

[23] Erik Brynjolfsson, Andrew McAfee, and Michel Spence, "New World Order, Capital, and Ideas in the Power Law Economy". Foreign Affairs, July/August 2014.

[24] OECD/Korea Policy Center, Growing Unequal? Income Distribution and Poverty in OECD Countries. 2010.

[25] OECD/Korea Policy Center, Society At a Glance 2011, page 67.

[26] Samuelson, P. A. Economics, 8th ed. 1970, p. 745.

[27] OECD, Better Life Index, 2014.

[28] UN, World Happiness report 2016.

[29] Yeon-hap News, in Korea, 2011.12.10. 